\title{
ANALISIS KESALAHAN DALAM MENGGUNAKAN QUESTION TAG OLEH MAHASISWA SEMESTER DUA PROGRAM STUDI MANAJEMEN UNIVERSITAS MH. THAMRIN
}

\author{
Akhmad Subkhi Ramdani', Noerlina Anggraeni ${ }^{2}$ \\ 1,2 FKIP, Universitas Mohammad Husni Thamrin
}

Correspondence author: Akhmad Subkhi Ramdani, email: akhmad.ramdani1988@gmail.com

\begin{abstract}
ABSTRAK
Question tag adalah salah satu jenis pertanyaan yang paling sering muncul dalam percakapan. Namun, dalam pelaksanaannya banyak mahasiswa yang tidak bias menjawab pertanyaan jenis ini dengan benar. Tujuan dari penelitian ini adalah untuk mengetahui bagaimana kemampuan mahasiswa semester dua Programm Studi Manajemen Universitas MH.Thamrin dalam menggunakan Question tag.

Selanjutnya, data penelitian ini dikumpulkan menggunakan penelitian kuantitatif dengan desain deskriptif. Peneliti menggunakan tes untuk mengumpulkan data dan untuk menganalisis pemahaman mahasiswa terhadap Question tag. Selain itu, tes ini juga menggunakan Cronbach Alpha untuk menemukan reliability. Kemudian, dalam menganalisis data, peneliti menggunakan statistik deskriptif melalui langkah-langkah berikut: 1) memberikan skor pada tes mahasiswa, 2) menemukan nilai rata-rata dari skor mahasiswa, 3) mengubah skor menjadi persentase, dan 4) menggunakan interval untuk menemukan pemahaman mahasiswa dalam penggunaan Question tag. Berdasarkan hasil analisis data, diketahui bahwa kemampuan mahasiswa semester dua Program Studi Manajemen dalam menggunakan Question tag dapat dikatakan baik dengan hasil 81,25\%. Namun, peneliti juga menemukan akan adanya interferensi bahasa yang menyebabkan mahasiswa mendapatkan 28,75\% kesalahan dalam menjawab soal.
\end{abstract}

Kata kunci, pemahaman mahasiswa, question tags

\begin{abstract}
The question tag is one of the most common types of questions that arise in conversation. However, in practice, many students cannot answer this type of question correctly. The purpose of this study was to determine how the ability of the second semester students of the MH Thamrin University Management Study Program in using the Question tag.

Furthermore, this research data was collected using quantitative research with a descriptive design. Researchers used tests to collect data and to analyze students' understanding of the Question tag. In addition, this test also uses Cronbach Alpha to find reliability. Then, in analyzing the data, the researcher used descriptive statistics through the following steps: 1) giving scores on student tests, 2) finding the average value of student scores, 3) converting scores into percentages, and 4) using intervals to find understanding students in using the Question tag. Based on the results of data analysis, it is known that the ability of students in the second semester of the Management Study Program in using Question tags can be said to be good with a result of $81.25 \%$. However, researchers also found that there was language interference which caused students to get $28.75 \%$ errors in answering the questions.
\end{abstract}

Keywords, pemahaman mahasiswa, question tags

\section{PENDAHULUAN}

Bahasa merupakan hal yang sangat penting dan mendasar dalam kehidupan manusia. Hal ini disebabkan karena bahasa digunakan sebagai media dalam menyampaikan pikiran dan perasaan manusia baik secara lisan maupun tulisan. Dari sekian banyaknya bahasa yang ada 
di dunia, peneliti memilih bahasa Inggris dalam penelitian ini karena bahasa inggris merupakan salah satu bahasa internasional yang paling sering digunakan oleh masyarakat Indonesia. Masyarakat Indonesia menerapkan bahasa inggris sebagai bahasa asing dan diajarkan di setiap tingkat pendidikan, mulai dari sekolah dasar sampai dengan perguruan tinggi. Dengan kata lain, semua mahasiswa pendidikan tinggi mengetahuinya. Di samping itu, seperti halnya bahasa lain yang ada diseluruh dunia, bahasa Inggris yang dipilih oleh peneliti untuk menjadi bahasa yang digunakan dalam penelitian inipun memiliki aturan tata bahasa.

Dalam aturan tata bahasa tersebut, terdapat sebuah jenis kalimat pernyataan yang disebut dengan Question tag. Question tag adalah salah satu pertanyaan yang paling sering muncul dalam percakapan sehari-hari. Menurut Byrd dan Benson dalam Hidayat (2015) "Question tag adalah kalimat atau pernyataan yang menggunakan pertanyaan di akhir kalimat itu sendiri". Thomson dan Martinet dalam Indriyati (2007) juga berbagi gagasan yang sama bahwa "Question tag adalah jenis kalimat yang digunakan oleh pembicara untuk meminta persetujuan pendengar dan konfirmasi sesuatu yang dia tidak yakin". Dengan kata lain, Question tag adalah jenis pertanyaan yang digunakan untuk mengkonfirmasi tentang sesuatu yang meragukan seorang pembicara, dan itu perlu persetujuan atau konfirmasi untuk memastikan argumen pembicara tersebut terhadap pendengar.

Beberapa penelitianpun telah dilakukan berkaitan dengan Question tag ini, diantaranya: (1) Retno Indriyati (2007), dia menemukan bahwa kesulitan yang dihadapi oleh mahasiswa dalam Question tag adalah mengidentifikasi pernyataan itu dengan "are"; (2) Hans (2013), dia juga menemukan bahwa kebalikan polaritas yang diperlukan dalam Question tag bermasalah bagi sebagian besar mahasiswa. Alasan mengapa peneliti tertarik pada Question tag adalah karena sebagian besar mahasiswa merasa bingung dan tidak dapat memberikan jawaban yang benar ketika peneliti bertanya kepada mereka menggunakan Question tag. Lebih jauh lagi, Quirk dan Greenbaum dalam Lukácsi (2008) mengklasifikasikan "Question tag menjadi tiga jenis utama bersama dengan pertanyaan yes-no dan pertanyaan -wh. Dengan kata lain, Question tag digunakan hampir setiap kali dalam percakapan atau sering muncul”. Oleh karena itu, peneliti berasumsi bahwa masalah ini perlu diselesaikan.

\section{METODE}

Data penelitian ini dikumpulkan menggunakan penelitian kuantitatif dengan desain deskriptif. Peneliti menggunakan tes untuk mengumpulkan data kuantitatif dan untuk menganalisa 
pemahaman mahasiswa terhadap Question tag. Tes yang digunakan sebagai instrument penelitian ini sebelumnya dibuatkan kisi-kisi untuk dilakukan uji validitas dan reliabilitas.

Selain itu, partisipan dalam penelitian ini adalah mahasiswa semester dua Program Studi Manajemen Universitas MH. Thamrin yang berjumlah delapan orang. Penelitian ini dilakukan selama 1 bulan, yakni pada bulan Mei 2020 .

Selanjutnya, dalam menganalisis data, peneliti menggunakan statistik deskriptif melalui langkah-langkah berikut: 1) Memberikan skor pada tes mahasiswa; (2) Menemukan rata-rata dari skor mahasiswa. Dalam menemukan rata-rata, peneliti menggunakan rumus yang dikemukakan oleh Johnson dan Christensen (2008) Mean $=\frac{\sum X}{n} ;$ (3) Mengubah skor menjadi persentase. Setelah nilai rata-rata didapatkan, maka peneliti merubah nilai tersebut kedalam bentuk persen dengan menggunakan rumus $=\frac{t s}{t n} \times 100 \%$; dan (4) Menggunakan interval. Penggunaan interval diperlukan untuk melihat tingkat pemahaman mahasiswa dalam menggunakan Question Tag.

\section{HASIL DAN PEMBAHASAN}

Peneliti telah memberikan tes kepada delapan orang mahasiswa program studi S1 manajemen Fakultas Ekonomi dan Bisnis, Universitas MH. Thamrin. Tes ini terdiri dari dua bagian yakni lisan dan tertulis yang masing-masing berisi lima pertanyaan. Soal-soal yang diberikan ini sebelumnya telah dilakukan uji validitas dan reliabilitas terlebih dahulu. Pertanyan-pertanyaan ini diperlukan untuk mengetahui kemampuan siswa dalam menggunakan question tag baik dalam bentuk tulisan maupun lisan.

Setelah peneliti mendapatkan jawaban dari tes yang telah diberikan kepada para mahasiswa, peneliti kemudian memberikan skor untuk test tersebut. Skor yang telah didapatkan kemudian dicari rata-ratanya dan dirubah kedalam bentuk persentase. Tahapan-tahapan tersebut seperti yang dijelaskan ini. 
Tabel Skor hasil test tertulis mahasiswa

\begin{tabular}{c|l|c|c|c}
\multirow{2}{*}{ NO. } & \multirow{2}{*}{ NAMA } & \multicolumn{2}{|c|}{$\begin{array}{c}\text { JUMLAH JAWABAN } \\
\text { BENAR }\end{array}$} & \multirow{2}{*}{ SKOR } \\
\cline { 3 - 4 } & & tertulis & lisan & \\
\hline 1. & $\mathrm{~W}$ & 5 & 3 & 80 \\
\hline 2. & $\mathrm{KJ}$ & 5 & 3 & 80 \\
\hline 3. & $\mathrm{H}$ & 5 & 3 & 80 \\
\hline 4. & $\mathrm{BH}$ & 5 & 2 & 70 \\
\hline 5. & $\mathrm{~S}$ & 5 & 3 & 80 \\
\hline 6. & $\mathrm{CE}$ & 5 & 3 & 80 \\
\hline 7. & $\mathrm{WR}$ & 5 & 3 & 80 \\
\hline 8. & $\mathrm{~L}$ & 5 & 3 & 80 \\
\hline \multicolumn{4}{|c|}{ JUMLAH } & 650 \\
\hline \multicolumn{4}{|c|}{ RATA-RATA }
\end{tabular}

$$
\begin{aligned}
& \text { Mean }=\frac{\sum X}{n} \\
& \text { Mean }=\frac{\sum(\text { skor })}{\text { jumlah mahasiswa }} \\
& \text { Mean }=\frac{650}{8} \\
& \text { Mean }=81,25
\end{aligned}
$$

Setelah mendapatkan nilai rata-rata mahasiswa, peneliti kemudian merubah nilai tersebut ke dalam bentuk persentase dengan menggunakan rumus sebagai berikut:

$$
\begin{aligned}
& p=\frac{t s}{t n} \times 100 \% \\
& p=\frac{650}{8} \times 100 \% \\
& p=81,25 \%
\end{aligned}
$$

\begin{tabular}{|c|c|}
\hline $\begin{array}{c}\text { Rentang persentasi kemampuan } \\
\text { peserta }\end{array}$ & kategori \\
\hline $85-100 \%$ & Very good (sangat baik) \\
\hline $75-84 \%$ & Good (baik) \\
\hline $60-74 \%$ & Fair (cukup) \\
\hline $40-59 \%$ & Weak (lemah) \\
\hline $0-39 \%$ & Poor (sangat lemah) \\
\hline
\end{tabular}

Berdasarkan hasil data di atas, diketahui bahwa kemampuan mahasiswa semester dua Program Studi Manajemen dapat dikatakan baik. Hal ini sesuai seperti yang ditunjukkan table di bawah ini.

Tabel Rentang persentasi kemampuan peserta

Seperti yang telah dipaparkan sebelumnya bahwa peneliti membagi tes menjadi dua jenis: tertulis dan lisan. Pada tabel skor hasil test tertulis mahasiswa, dapat dilihat bahwa semua 
mahasiswa dapat menjawab pertanyaan tertulis dengan benar, namun untuk tes lisan, semua mahasiswa tidak ada yang mendapatkan nilai sempurna. Dengan kata lain, nilai mahasiswa untuk tes lisan adalah $28.75 \%$ yang berarti dikategorikan kedalam sangat lemah.

Berdasarkan hasil temuan dari penelitian yang telah disajikan di atas, diketahui bahwa kemampuan siswa dalam menggunakan Question Tag dapat dikatakan baik dengan 81,25\% pertanyaan dapat dijawab dengan benar. Namun kemampuan yang terkategorikan baik itu hanya untuk tes tertulis; sedangkan untuk tes lisan, kemampuan seluruh mahasiswa dikategorikan sangat lemah. Hal ini terlihat dari hasil tes lisan mereka dimana mereka hanya mendapatkan $28,75 \%$ untuk jawaban yang benar. Setelah peneliti melakukan analisis data, ditemukan bahwa kesalahan mahasiswa dalam menjawab soal yang diberikan ternyata untuk pertanyaan dengan jenis negatif.

Kemudian, untuk mencari tahu permasalahan tersebut, peneliti melakukan wawancara kepada para mahasiswa mengenai jawaban yang mereka berikan dalam tes lisan tersebut. Berdasarkan hasil wawancara dengan mahasiswa, diketahui bahwa, kelemahan mahasiswa dalam menggunakan Question Tag secara lisan ini ternyata dipengaruhi oleh interferensi Bahasa Indonesia. Interferensi bahasa merupakan sebuah penyimpangan yang terjadi pada norma bahasa baik bahasa pertama maupun bahasa yang sedang dipelajari oleh seorang pengguna dua bahasa. Interferensi bahasa ini muncul pada semua level bahasa: fonologis, morfologis, sintaktis, semantic, dan leksikal. Weinreich (1968). Kelemahan ini diketahui ketika peneliti mengajukan pertanyaan dalam bentuk Question Tag kepada para mahasiswa dimana mereka menjawab dengan norma yang sama seperti pada contoh di bawah ini.

1. Peneliti

mahasiswa

2. Peneliti mahasiswa
:You didn't take my pencil, did you?

: No, I didn't

: This isn't your pen, is it?

: No, it isn't 
Dalam norma bahasa Indonesia, sering kita dengar sebuah percakapan

1. penanya : kamu tidak ambil dompet saya kan?

penjawab : tidak, saya tidak ambil

2. Penanya : ini, bukan milikmu kan?

Penjawab : bukan.

Dengan kata lain, masyarakat Indonesia hampir tidak pernah menjawab iya, untuk pertanyaan (jenis Question Tag) yang bersifat negatif. Padahal, seperti yang kita ketahui, seharusnya jika seseorang dituduh melakukan sesuatu yang tidak dilakukannya dengan menggunakan pertanyaan (jenis Question Tag) yang bersifat negatif ini, dia menjawab iya; jika seseorang menjawab tidak, maka itu berarti dia melakukannya.

\section{KESIMPULAN DAN REKOMENDASI}

Berdasarkan hasil penelitian yang telah dipaparkan di atas, diketahui bahwa kemampuan mahasiswa dalam menggunakan Question Tag dapat dikatakan baik dengan 81,25\% pertanyaan dapat dijawab dengan benar. Namun, dari hasil tes lisan mereka hanya mendapatkan $28,75 \%$ untuk jawaban yang benar. Berdasarkan hasil wawancara dengan mahasiswa, diketahui bahwa, kelemahan mahasiswa dalam menggunakan Question Tag secara lisan ini ternyata dipengaruhi oleh interferensi Bahasa Indonesia. Interferensi bahasa merupakan sebuah penyimpangan yang terjadi pada norma bahasa baik bahasa pertama maupun bahasa yang sedang dipelajari oleh seorang pengguna dua bahasa. Interferensi bahasa ini muncul pada semua level bahasa: fonologis, morfologis, sintaktis, semantik, dan leksikal. Weinreich (1968).

Setiap bahasa di seluruh dunia memiliki tata bahasanya masing-masing, dimana terdapat beberapa kesamaan dan juga perbedaan terhadap bahasa lain. Demikian pula dengan bahasa inggris dan bahasa Indonesia. Maka dari itu, dalam menggunakan atau menerjemahkan suatu bahasa, seseorang harus mengikuti kaedah tata bahasa yang berlaku dalam bahasa tersebut.

\section{DAFTAR PUSTAKA}

Baker, D. (2015). Changing English: Tag Questions. ELT Journal Volume 69/3 July 2015; doi:10.1093/elt/ccv015. Oxford University Press.

Brasch, H. (2013). Investigating Swedish Pupils' Command of Canonical Question Tags with Reverse Polarity at Different Stages of Learning. Sweden: Inst för Sprâk Och Litteraturer 
Hidayat, R. (2015). An Analysis on Students' Ability in Using Question Tags at The Ninth Grade of One Junior Hign School in Jambi. Jambi: Repository FKIP Universitas Jambi.

Indriyati, R. (2007). The Profile of Students Mastery of Question Tags: The Case of The Third Year Students of SLTP Institut Indonesia Semarang. Faculty of Language and Art. State University of Malang. Semarang.

Krifka, M. (2015), Bias in Commitment Space Semantics: Declarative Questions, Negatied Questions, and Question Tags. Proceeding of SALT 25: 328-345, 2015. Berlin: Humboldt-Universität Berlin \& Zentrum für Allgemeine Sprachwissenschaft (ZAS).

Lukácsi, Z. (2008). Language and Gender: How Question Tags are Classified and Characterised in Current EFL Materials. Hungary: UPRT 2008. Empirical Studies in English Applied Linguistics. Lingua Franca Csoport.

Weinreich, Uriel. 1968. Language in Contact. Mouton: The Hauge-Paris 